\title{
Renata CZEKALSKA
}

Jagiellonian University in Kraków, Poland

r.czekalska@uj.edu.pl

\section{Robert KŁOSOWICZ}

Jagiellonian University in Kraków, Poland

robert.klosowicz@uj.edu.pl

\section{SATYAGRAHA AND SOUTH AFRICA}

\section{PART I: THE ORIGINS OF THE RELATIONSHIP \\ BETWEEN THE $I D E A$ AND THE $P L A C E$ \\ IN MAHATMA GANDHI'S WRITINGS}

ABSTRACT The article presents the results of research carried out mainly on Mahatma Gandhi's written statements which the authors refer to both a historical and socio-political background. It is the first part of the planned two-part study on mutual relations between Mahatma Gandhi's satyagraha and South Africa, therefore it is focused on the interdependencies between the origin of the idea and the place where it was invented. The authors seek to answer two main questions: 1) whether Gandhi has entered into a dialogue with the native people of South Africa, and 2) whether Gandhi's idea of non-violent fighting for social rights included the native population of South Africa. The study also presents an outline of the evolution of Gandhi's attitudes towards Africans and the Coloured People.

Keywords: Gandhi in South Africa; the idea of satyagraha; human rights; social equality 


\section{INTRODUCTION}

Mohandas Karamchand Gandhi (1869-1948) came to South Africa in 1893, as a budding lawyer who had completed his barrister's degree in London (1891) and who, having returned to India, could not find acceptable employment. South Africa was therefore a primarily pragmatic choice as Gandhi was offered a one-year contract to do legal work for an Indian firm in Pretoria. However, he remained in South Africa not for a year, but for over 20 years (returning to India in 1915). And it was there that he was first exposed to authorized racial discrimination, and where he had developed his philosophy of nonviolent struggle for human rights by organizing the South African Indian community to contest race-based laws and socioeconomic subjugation.

The aim of the article - which is intended as a two part study on interdependencies between Gandhi and South Africa - is to present possible mutual influences and their outcome. In Part I, we will reflect on the subject of the actual relationship between the origin of the Gandhian idea of satyagraha $a^{1}$ and the place where this idea was born, i.e. South Africa. We will also try to look into the question whether Gandhi entered into a dialogue with the native people of South Africa, and to what degree of involvement his idea of fighting for social equality - with his original tool named satyagraha - extended beyond the South African Indians. Therefore, the actual involvement of Gandhi with the interests of the South African Indians, as well as the position of the Indian population in the country, is only of secondary standing and it is treated here mainly as a background issue, to place Gandhi's actions in the socio-political context. ${ }^{2}$ As a further result of the conducted study, we will also present some remarks about the evolution of Gandhi's own attitudes towards Africans and the Coloured People. Our final goal will be to observe the influence of Gandhian ideas on the South African liberation struggle and their perception in present-day Africa. However,we intend to present this last issue in a separate study, planned as Part II of the article.

Being acutely aware of the need of an extensive work regarding the complex and two-way relationships between South Africa and Gandhi, we would like to underline

The term satyägraha, coined and developed by M.K. Gandhi, can loosely be translated as "insistence on truth" (in Sanskrit: satya 'truth'; agraha 'insistence') or "holding onto truth." Gandhi himself explains the meaning of the term in the following words: [t]he Satyagraha struggle of the Indians in South Africa lasted eight years. The term Satyagraha was invented and employed in connection therewith (p. 8). Truth (Satya) implies love, and firmness (agraha) engenders and therefore serves as a synonym for force. I thus began to call the Indian movement "Satyagraha," that is to say, the Force which is born of Truth and Love or non-violence... (pp. 71-72). Satyagraha is soul force pure and simple, and whenever and to whatever extent there is room for the use of arms or physical force or brute force, there and to that extent is there so much less possibility for soul force (p. 74) - all quotations in this footnote from: M.K. Gandhi, Satyagraha in South-Africa, trans. by V.G. Desai, Ahmedabad 2003 (electronic document published by Yann FORGET). In all the passages quoted in the article the original spelling has been retained.

2 For detailed, in-depth treatment of the issue, see: D. Du Bois, Labourer or Settler? Colonial Natal's Indian Dilemma 1860-1897, Durban 2011. 
that this article is of a preliminary nature and presents the results of research carried out mainly on Mahatma Gandhi's written statements which we refer to both a historical and socio-political background.

\section{SOCIO-POLITICAL SITUATION OF THE INDIAN MINORITY IN SOUTH AFRICA}

In larger numbers, Indians came to South Africa in the mid- $19^{\text {th }}$ century when they began to work on sugar cane plantations. Not satisfied with the work of the Africans, the owners of the plantations in Natal convinced the authorities to support the immigration of Indian coolies.

Negotiations were initiated with the Indian government in 1856, but it was not until 1859 that they were successfully concluded. The Indian government wanted certain definite guarantees regarding the welfare of the queen's Indian subjects before allowing them to work in Natal. As a result, Natal Law 14, of 1859, established a Coolie Immigration Department, which was to be the responsibility of the Coolie Immigration Agent. This department was to receive the monies due from employers, who were to pay three-fifths of the cost of Indian immigration. The agent was also required to keep a register of Indian immigrants and to assign them to employers. ${ }^{3}$

The first group came to Natal in 1860 on two ships, from Madras and Calcutta. ${ }^{4}$ They were very poorly paid - from 10 to 12 shillings a month and the upkeep. On completing a five-year contract they earned the right to chose a place to live and to work. Since 1883, after completing the five-year contract they were even given plots of land in Natal. ${ }^{5}$ In

R.A. Huttenback, 'Indians in South Africa, 1860-1914: The British Imperial Philosophy on Trial', The English Historical Review, Vol. 81, No. 319 (1966), p. 273, at <http://dx.doi.org/10.1093/ehr/ LXXXI.CCCXIX.273>.

4 A special category of labourers brought from India were the "indentured workers." According to Duncan Du Bois, the first group of ...indentured Indians arrived in November 1860. The description of the women and children amongst them as being "dead stock" because planters wanted strong men to tackle the dense coastal bush, aptly summed up the colonial view of the immigrants. They were seen purely as units of labour. See: D. Du Bois, 'The "Coolie Curse”: The Evolution of White Colonial Attitudes towards the Indian Question, 1860-1900', Historia, Vol. 57, No. 2 (2012), p. 37-67, at <http://www.scielo.org. $\mathrm{za} /$ scielo.php?script=sci_arttext\&pid=S0018-229X2012000200002\&lng=en\&tlng=en >, 20 May 2015.

5 The Indian immigrants were to complete five years of indentured service at wages of not less than ten shillings a month. Law 14 of 1859 empowered indentured Indians to purchase back the last two years of their obligation by a payment of $£ 5$, but this provision was removed in 1864 . At the end of five years the immigrants became free. Ten years after their arrival, immigrants became eligible for a free return passage to India, although they could remain in Natal if they wished, and the Governor could, at his discretion, commute the cost of the return passage into a grant of Crown land. The Indian government also imposed certain regulations of its own, and the Government of India's Act 23 of 1860 established standards for the feeding, clothing, and general care of the labourers, the proportion of women that had to be included in any consignment, and the method of recruitment. R.A. Huttenback, 'Indians in South Africa...,' pp. 273-274. 
1865, approximately 6500 Indians were already living in $\mathrm{Natal}^{6}$ and at the beginning of the $20^{\text {th }}$ century their numbers came to over 100,000 , which was more than the white citizens of the colony. It is assumed that in the next 50 years, approximately 150,000 Indians came to South Africa. ${ }^{7}$ With the passage of time, the Indian settlers began working not only in agriculture, but also in industry, and many of them set up their own small businesses, as artisans and shopkeepers, and therefore created competition for the white entrepreneurs. In Transvaal they settled mainly in the city of Durban and along the Durban-Johannesburg road. According to Duncan Du Bois, the Indian stepping into the domain of the white settlers induced a phenomenon known as coolie-ism. He is of the opinion that ...in tracing the evolution of white colonial Natal's Indian question in the late 1870s, we find evidence of the first real signs of discord and disapprobation. The term "coolie-ism" was used to express disapproval of the inroads Indians were making into the hitherto exclusively white settler preserve of commerce. ${ }^{8}$

The first reasons for Indian settlement in South Africa have been aptly summarised by E.P. Roberts in the following words: The introduction of Indians into South Africa was due to the discovery in the 1850s that the soil and climate of Natal were ideal for the successful cultivation of sugar. The one obstacle blocking the establishment of a thriving plantation economy was a lack of labour, as the local African population produced few willing workers. The eyes of the planters consequently turned hungrily towards India, which had already come to the rescue of Mauritius, Trinidad, St. Lucia and Granada, when they had faced a similar problem. As the Natal Mercury stated in April 1859: "The fate of the Colony hangs on a Thread and that thread is Labour."

The growing Indian population and, with each decade, the growing economic competition caused anxiety and the feeling of insecurity among the white citizens of South Africa, especially since $[w]$ hat had not been anticipated [...] was the influx of a small group of free Indians, mainly Muslims, from Gujerat on the west coast of India, who came to Natal, at their own expense, to engage in commerce and particularly in the retail busi-

6 Between 12 October 1860 and 5 February 1861, five vessels left the Indian ports of Madras and Calcutta for Natal, carrying 1029 male adults, 359 women (25 per cent of the total being the minimum until 1866, when it was raised to 50 per cent), and some children. Between 1863 and 1866, 2814 more male adults disembarked in Durban. The importation of Indian labour had an immediate effect on the economy of Natal. Ibid., pp. 273-274.

7 A History of Indian Settlement in KwaZulu-Natal, at <http://www.zulu.org.za/archive/a-history-of-indian-settlement-in-kwazulu-natal-F58490>, 2 May 2015. According to Duncan Du Bois, the exact population figures for 1900 were: 64951 whites and 70369 Indians. See: D. Du Bois, The Evolution of the Indian Question in Natal - 1860-1897, p. 14, at <http://www.kznhass-history.net/files/seminars/ Dubois2011.pdf>, 20 June 2015.

8 Idem, 'The "Coolie Curse"...'

$9 \quad$ P.E. Roberts, History of British India under the Company and the Crown, London 1952, pp. 383-384; Natal Mercury, 28 April 1859, quoted in L.M. Thompson, Indian Immigration into Natal (1860-1872), Cape Town 1952, p. 8. Here it is worth to underline the observation of Duncan Du Bois, who states that By the mid-1880s, Natal's Indian dilemma had become something of a paradox: white resentment at the Indian presence was reaching new levels of intensity at the same time that the need for Indian labour was reaching new levels of necessity - D. Du Bois, 'The "Coolie Curse"...' 
ness. These "Passenger Indians" or "Arabs," who began arriving in the 1880s, were soon providing competition for white merchants, and consequently aroused great resentment. To make matters worse, the Indian population of Natal soon outstripped the European. By 1894 there were already 43,000 Indians to 40,000 whites, not to mention some 700,000 Africans. ${ }^{10}$

At first, an attempt was made to repatriate the former coolies to India, however, due to the decision of the Indian colonial administration ${ }^{11}$ these efforts proved unsuccessful. ${ }^{12}$ Then, in result, the rights of this social group were gradually and lawfully restricted. The coolies stopped being given plots of land, the merchants who were not keeping their account books in English were refused licences, Indians were deprived of the right to vote. Moreover, a special tax of $£ 3$ per annum was imposed on those Indians who worked for white employers, and the mixed marriages between the whites and the Indians became a crime in the eyes of law. In Transvaal, such couples were refused not only political but also civil rights, they were not allowed to own any property, and were forced to live in special ghettoes.

However, the discovery of new gold resources in Witwatersrand ${ }^{13}$ caused the necessity to employ approximately 130,000 workers. Not too many were interested in working 1500 meters under the ground and for rather low wages. Therefore, a decision was made to once again import the "Asiatic work force." Otherwise, the competition between the farms and the mining industry over the African workers could have become rather harsh. Due to the fact that the colonial Indian authorities refused the permission for further recruitment of Indian coolies - because of the increasing discrimination against them in South Africa ${ }^{14}$ - it was decided that the workers should be brought from China. The Boer politicians very strongly opposed this decision, for they feared the increase of the none-white population in South Africa. Moreover, they were afraid that the Chinese, just as the Indians before them, would not leave South Africa after completing their contracts. ${ }^{15}$

10 R.A. Huttenback, 'Indians in South Africa..., p. 275.

11 In the years 1858-1948 India was ruled by the Governor-General with the title of Viceroy, subordinate to the Secretary of State in London.

12 Duncan Du Bois, after analysing the data given in: S. Bhana, Indentured Indians in Natal 1860-1902. A Study Based on Ships' Lists, Durban 1987, states that Between 1860 and 1911 a total of 152,184 Indian immigrants came to Natal. Of those, 23 percent returned to India by the time indentured immigration ceased in 1911. See: D. Du Bois, 'The "Coolie Curse”...'

13 Important gold mining basin around Johannesburg.

14 More than two decades elapsed before white colonists in Natal began to question the consequences of Indian immigration. The 278 percent increase in the size of the Indian population between 1876 and 1886 transformed white opinion. Appreciation of the role Indians played in the economy of the Natal Colony mutated into alarm at the social and political threat which the growing Indian population was seen to pose to white settler security - D. Du Bois, 'The "Coolie Curse"...'

15 The first contingent of 10,000 Chinese coolies came to SA in 1904, in: J. Balicki, Historia Burów. Geneza państwa apartheidu [A History of Boers. The Origins of the Apartheid State], Wroctaw 1980, p. 159. According to Charles H. Feinstein, The scheme was emulated [...] in 1904, when mine owners reacted to serious shortage of labour by persuading the authorities to agree to the importation of inden- 
Granting the Union of South Africa the status of a dominion was a major breakthrough for the region, both politically and economically. In the sphere of economy, it certainly benefited from the abolition of customs borders and the inflow of foreign capital investments. Social matters were, however, much more complicated. The following years were marked by the consolidation of Afrikaner nationalism and by managing the complex racial situation through legislation. Even before the outbreak of World War I, the Parliament of the dominion passed several laws, giving legal expression to the discrimination against non-Europeans, however, two of them were of the greatest significance ${ }^{16}$ : the Mines and Works Act of $1911^{17}$ and the Native Land Act of 1913. ${ }^{18}$ The first authorized the Governor General to settle the matter of the documents of competence, required in the mines and factories for taking up senior positions, by way of orders. The second specified the principle of racial segregation with regard to land ownership. ${ }^{19}$

The Union authorities also began to further limit the rights of the South African Indians, the majority of whom were born in South Africa, which caused waves of protest. In consequence, the first Indian political organization in South Africa - the Natal Indian Congress, co-founded by M. K. Gandhi - was created in 1894. The politics of the NIC was crucially shaped by the social and economic stratification of the Indian population and was dominated by merchants and traders who sought to maintain their rela-

tured labour from China, with the understanding that they would not compete with the white workers but would be employed only on unskilled work. [...] However, this "Chinese slavery" aroused such hostility in Britain that it contributed to the Liberal Party victory in the general election of 1906, and the new government probibited the issue of further licences to bring in indentured labourers. Those already on the Rand were sent home as their contracts expired - Ch.H. Feinstein, An Economic History of South Africa. Conquest, Discrimination, and Development, New York 2005, p. 54 (Ellen McArthur Lectures).

16 As discussed by Duncan Du Bois, Gandhi proclaimed strong opposition to both these Acts, and was active in voicing protest against them in India as well as in Britain. See: D. Du Bois, Labourer or Settler?..., chapters $8 \& 9$.

17 1911. Mines and Works Act no 12, Nelson Mandela Centre of Memory, at <https://www.nelsonmandela.org/omalley/index.php/site/q/03lv01538/04lv01646/05lv01736.htm>, 2 May 2015.

18 1913. Natives Land Act no 27, Nelson Mandela Centre of Memory, at <https://www.nelsonmandela. org/omalley/index.php/site/q/03lv01538/04lv01646/05lv01745.htm>, 2 May 2015.

19 The objections of the native population to land laws for natives led in 1912 to the emergence of the African National Congress - ANC, the first African political organization. Here it may also be worth noting that the role of Gandhi in creating the ANC? is not the subject of discussion in this article, since we are trying to focus on his involvement with the issues related to the underprivileged natives of South Africa and not his engagement with the "Indian question." However, it might be of interest that Gandhi's attention was not only set on creating an organization exclusively for South African Indians but also that he differentiated the members of this community and was selective in who he supported. According to Duncan Du Bois, it is made evident by the fact that in "Indian Opinion" there was no mention of the human rights abuse on sugar plantations owned by Reynolds Bros. He writes: Press silence [...] attended the work of the Reynolds Inquiry in 1906. [...] Gandhi's own newspaper, Indian Opinion, was part of that silence. [...] in campaigning for equal rights for Indians, Gandhi focused on the merchants and traders rather than the indentured - D. Du Bois, 'Collusion and Conspiracy in Colonial Natal: A Case Study of Reynolds Bros and Indentured Abuses 1884', Historia, Vol. 60, No. 1 (2015), p. 105, at <http://dx.doi.org/10.17159/2309-8392/2015/v60n1a6>, 20 June 2015. 
tively privileged position in the local hierarchy. in part by claiming their rights as subjects of the British Empire. ${ }^{20}$

In 1911 there were approximately 150,000 Indians living in the Union. Out of this number, 133,000 lived in Natal, 7,000 in the Cape Province, 11,000 in Transvaal and about one hundred in the Orange Free State (where they were prohibited to enter by law). In 1914, the talks began between Gandhi and general Jan Christiaan Smuts, the Union's Minister for Defence at the time, which led to an agreement that resulted in the Relief $A c t^{21}$ under which the tax levied on every adult Indian in the amount of $£ 3$ was abolished. Some other rules, such as the obligation for the educated Indians to give their fingerprints when registering, were also eradicated. After signing the agreement, which was not satisfactory for the Indian population of South Africa (some rules and regulations regarding land ownership, conducting trade and the freedom of movement remained unchanged), Gandhi left the country, never to come back.

\section{M.K. GANDHI AND HIS ATTITUDE TOWARDS THE NATIVE PEOPLE OF SOUTH AFRICA}

On the basis of his Collected Works, ${ }^{22}$ it is certainly possible to see both the development of Gandhi's approach to the Africans and also the change of his interest in their life-conditions.

The first period of his stay in South Africa can be marked by the year of his arrival (1893) and the year of the advent of the satyagraha movement (1906). During these thirteen years Gandhi as a lawyer and a civil servant was involved mainly in improving the conditions of the South African Indian community. He proposed self-support initiatives and tried negotiating with the authorities in the matters that were of legal, and not of political, nature. What triggered the change in Gandhi's attitude was the implementation of the Asiatic Law Amendment Ordinance of Transvaal in 1906, a humiliating law that was enacted to enforce the registration of Indians in the province. As a reaction, in 1907 Gandhi launched a passive resistance movement, which began the second period of his South African years. As a result, he was for the first time imprisoned (January 1908) and he had also ended his legal practice. Furthermore, at that time he came out with the idea of satyagraha that he characterized as the defiance of unjust

20 V. Padayachee, 'Struggle, Collaboration and Democracy: The "Indian Community" in South Africa, 1860-1999,' Economic and Political Weekly, Vol. 34, No. 7 (1999), p. 393. See also: M. Swan, Gandhi. The South African Experience, Johannesburg 1985, p. 441 (New History of Southern Africa Series), where the author gives the following opinion: Their politics far from unifying the Indian population as has been asserted in the past, were directed specifically towards attaining white recognition of the fundamental differences between the two major social groups in the community: merchants and workers.

21 1914. Indian Relief Act, Nelson Mandela Centre of Memory, at <https://www.nelsonmandela.org/ omalley/index.php/site/q/03lv01538/04lv01646/05lv01746.htm>, 2 May 2015.

22 For The Collected Works of Mahatma Gandhi Online (in one hundred volumes), GhandiServe Foundation, at <http://www.gandhiserve.org/e/cwmg/cwmg.htm>, 12 November 2014. 
laws, acceptance of the consequences, strict observance of non-violence, suffering without retaliation, readiness to compromise, and determination never to surrender.

At first the movement meant primarily resistance against injustice, but not against the regulations of the State, as Gandhi still considered himself a faithful citizen of the British Empire. This simply meant that while his attitude towards Britain remained so, that is until the 1920s, there was no possibility of any joint actions with the Africans, for they did not enjoy the status of citizens of the Empire and therefore their cause was different from the Indian one. This is how Gandhi justifies his opinion: I felt that if I demanded rights as a British citizen, it was also my duty, as such, to participate in the defence of the British Empire. ${ }^{23}$

Moreover, apart from not challenging the legitimacy of the European rule in South Africa, the Indian community there did not need to struggle against apartheid. This comparatively small group of people was only fighting for the rights that they had been solemnly promised by the British and that they had to some extent enjoyed until the local European settlers gained self-government ${ }^{24}$ and began to oppress the Indian settlers.

Gandhi's writings in fact give rather strong evidence as to why he was afraid of any associations between the problems of the native Africans, whom he names the "sons of the soil," and the Indian immigrants. He was convinced that undertaking any steps to support the Africans' struggle for their rights would induce fear among the Europeans that would cause their hostility towards the Indian community. He seems to have been careful to the point that in his writings he does not give any account of his interactions with the leaders of the African population. ${ }^{25}$ Gandhi therefore reveals himself as a true

23 M.K. Gandhi, An Autobiography or The Story of My Experiments with Truth, trans. by M. Desai, Ahmedabad (electronic document; no year of publication given), p. 214.

24 The "pro-Boer" Liberal Party in Britain came to power in January 1906. In February 1906 an election was held with Het Volk ("The People" - a political party established in Transvaal in 1904; its first leaders were Louis Botha and Jan Smuts) featuring themselves as an alternative to the mining capitalistic Progressive Party. Het Volk won the election gathering 37 of 69 seats. Louis Botha became Prime Minister of the Transvaal and Jan Smuts took the position of its colonial secretary. By 1908, the Boers had won control of the Natal, Orange River and Transvaal colonies.

25 There are some very definite opinions on this subject which regard Gandhi's actions as completely indifferent to the cause of the South African native population. For example, Gandhi's political philosophy gradually evolved and distanced itself from the narrow views from about 1906 as he immersed himself in broader local struggles. Yet even the 1913 Natal Indian Strike, which forced a minor amelioration in the status of Indian South Africans, it has been argued, resulted principally from the spontaneous response of a brutally oppressed indentured workforce to their appalling working and living conditions, rather than as a result of the organised efforts of Gandhi or the merchant-dominated NIC. At another level organised political and social relations between this community and South Africans of "other races" were complex in character. Organised political relations with the African majority simply did not exist at any level before the mid-1940s, despite the efforts of some academics and media figures to rewrite their history in romantic terms. The early NIC was determined to keep its distance from the Africans. In 1936 The Indian Opinion argued against an alliance with the Africans, who it was said were at an "underdeveloped stage." Thus, for example. by 1941, Indian South Africans were still being urged to maintain a separate struggle for social change - V. Padayachee, 'Struggle, Collaboration and Democracy..., p. 393. 
politician, fighting the cause of "his" people and securing their interests in every possible manner. In his autobiography he writes: I saw that South Africa was no country for a self-respecting Indian, and my mind became more and more occupied with the question as to how this state of things might be improved. ${ }^{26}$

All the above-mentioned remarks confronted with the content of Gandhi's collected works allow for the observation that only in the later part of Gandhi's writings - which paradoxically covers the time he spent away from South Africa - does the question of freedom and equality become far more universally understood by him. Therefore, he sometimes refers satyagraha to non-Indian (also South African) instances.

\section{THE ATTITUDE TOWARDS THE NATIVE AFRICANS IN M.K. GANDHI'S WRITINGS}

While searching through the Collected Works of Mahatma Gandhi one can be a little astonished when observing that until the end of the fifth volume (and sporadically also later, until volume VIII), Gandhi sometimes refers to the Africans as "kaffirs" ${ }^{27}$ " and now and then does not avoid making depreciating comments about them. He also seems to be convinced about the superiority of Indians over the native population of the country, which can be seen for example in the following instances:

A general belief seems to prevail in the Colony that the Indians are little better, if at all, than savages or the Natives of Africa. Even the children are taught to believe in that manner, with the result that the Indian is being dragged down to the position of a raw Kaffir. (Collected Works, Vol. 1, p. 193). ${ }^{28}$

Ours is a continual struggle against a degradation sought to be inflicted upon us by the Europeans, who desire to degrade us to the level of the raw Kaffir whose occupation is hunting, and whose sole ambition is to collect a certain number of cattle to buy a wife with and, then, pass his life in indolence and nakedness. (Collected Works, Vol. 1, p. 407$) \cdot{ }^{29}$

26 M.K. Gandhi, An Autobiography..., p. 131.

27 The term kaffir (from Arabic käfir 'one denying God; an infidel') was a derogatory way to name the black population in South Africa. It was first used by the Muslims to denote the non-Muslim Africans in parts of the Indian Ocean world. See: S.L. Danver, Native Peoples of the World. An Encyclopedia of Groups, Cultures, and Contemporary Issues, New York 2015, p. 535. From the beginning of the $20^{\text {th }}$ century, so during Gandhi's times in South Africa, it was in common use, to the point than even the educated Zulus that accepted Christianity used it for those of their fellowmen who were not baptised. The fact that Gandhi uses this term is perhaps slightly astonishing because it was used as a pejorative denomination also in India, so he was definitely aware of its nature.

28 In an Open Letter to the members of the Natal Legislature in December 1894.

29 On September 26, 1896, Gandhi delivered an address at a public meeting in Bombay on the grievances of South African Indians. He elaborated on the insults, repressive laws and humiliations faced by Indians, and was carried away by his anger to make an insensitive and thoughtless statement reflecting the prevalent prejudices about the Africans. The address was published by The Times of India (September 27, 1896) and Bombay Gazette (September 27, 1896). 
Your petitioner has seen the Location intended to be used by the Indians. It would place them, who are undoubtedly infinitely superior to the Kaffirs, in close proximity to the latter. (Collected Works, Vol. 2, p. 270). ${ }^{30}$

Among the "notes on the Indian question" he prepared in India in May 1902, he wrote about Natal: The indigenous people, that is, the Zulus, are a fine body of men, but they are very lazy, and will with difficulty work at a stretch for six months. (Collected Works, Vol. 2, p. 464). In Satyagraha in South Africa he developed this issue in the following manner: [...] the English arrived. They settled in Natal, where they obtained some concessions from the Zulus. They observed that excellent sugar cane, tea and coffee could be grown in Natal. Thousands of labourers would be needed in order to grow such crops on a large scale, which was clearly beyond the capacity of a handful of colonists. They offered inducements and then threats to the Negroes in order to make them work but in vain, as slavery had been then abolished. The Negro is not used to hard work. He can easily maintain himself by working for six months in the year. Why then should he bind bimself to an employer for a long term? The English settlers could make no progress at all with their plantations in the absence of a stable labour force. They therefore opened negotiations with the Government of India and requested their help for the supply of labour. ${ }^{31}$

In light of the previous quotations the year 1906 appears to be a breaking point in Gandhi's attitude towards the native African population. It was the year when he decided to serve as the head of the Stretcher Bearer Corps of the Natal Militia fighting the rebellion of the Zulus. ${ }^{32}$ Not really understanding the causes behind the rebellion, Gandhi urged the Indian population in South Africa to join the war through his columns in Indian Opinion: "If the Government only realised what reserve force is being wasted, they would make use of it and give Indians the opportunity of a thorough training for actual warfare."33

30 A quote from a petition Gandhi drafted in 1899 concerning the designation of a location for the Indian settlers.

31 M.K. Gandhi, Satyagraha in South-Africa, p. 21.

32 In 1906 the difficult situation in Natal began to escalate, when Natal's administrators began to collect a newly imposed poll tax (head tax) from adult unmarried men. Many Zulu people and chiefs had verbally protested the new tax, to no effect. The tax, apart from being a source of income for the province, was also a means to force the Africans to take work on the farms and in the mines. Upon learning of the introduction of the tax, riots started among the African population and two white police officers were killed, which caused repressions from the government. (More on this issue, see: S. Redding, 'A Blood-Stained Tax: Poll Tax and the Bambatha Rebellion in South Africa', African Studies Review, Vol. 43, No. 2 (2000), pp. 31-32, at <http://dx.doi.org/10.2307/524983>). In response, an open rebellion broke up among some of the Zulus which went down in history under the name of the Bambatha Rebellion, from the name of a local chief Bambatha, who headed the armed rebellion against the whites. The rebellion was bloodily suppressed by Natal militia troops and volunteers from other provinces of South Africa. The turning point was the massacre of the rebels, on 10 June 1906, near Mome Gorge, where the Zulu leader was killed. As a result of the rebellion about three thousand Zulus were killed, just as many were arrested and 24 chiefs were forced to go into exile. In the regions which gave support to the rebels, the homes and crops of Africans were destroyed. (More on this subject in an extensive study of the Zulu Rebellion by J. Stuart, A History of the Zulu Rebellion 1906 and of Dinuzulu's Arrest, Trial and Expatriation, London 1913).

33 Indian Opinion, 18 November 1905, in The Collected Works of Mahatma Gandhi, Vol. 5, p. 11. 
Some years later, in his Autobiography, he made an attempt to justify this decision by writing the following words: The Zulu "rebellion" was full of new experiences and gave me much food for thought. The Boer War had not brought home to me the horrors of war with anything like the vividness that the "rebellion" did. This was no war but a man-hunt, not only in my opinion, but also in that of many Englishmen with whom I had occasion to talk. To hear every morning reports of the soldiers' rifles exploding like crackers in innocent hamlets, and to live in the midst of them was a trial. But I swallowed the bitter draught, especially as the work of my Corps consisted only in nursing the wounded Zulus. I could see that but for us the Zulus would have been uncared for. This work, therefore, eased my conscience. ${ }^{34}$ However, it is an interpretation of then quite distant facts. The statement given at the time of the Zulu rebellion - and quoted below - prevailed in Gandhi's thinking for many more years.

The following statement can be quite easily interpreted as the words of a citizen of the Empire who understood that the Zulu rebellion gave him an opportunity to prove his loyalty to the British. Moreover, they are also a hint of Gandhi's attitude towards the Zulus: What is our duty during these calamitous times in the Colony? It is not for us to say whether the revolt of the Kaffirs is justified or not. We are in Natal by virtue of British power. Our very existence depends upon it. It is therefore our duty to render whatever help we can. ${ }^{35}$

Paradoxically, in the same year of 1906, Gandhi had also decided to oppose the new registration law in Transvaal which made him an enemy of the state. The Asiatic Ordinance requiring Indians to register with fingerprints, issued by the Transvaal Government, brought a visible change in Gandhi's views regarding the question of the Africans and, in consequence, in his approach towards the indigenous people. His reaction was categorical as he felt that the Indians were treated as criminals in a country where they were supposed to have enjoyed all the citizens' rights. Perhaps then he began to notice at least a vague analogy between the fate of the South African Indians and the native population of the country. And perhaps this is why he openly acknowledged the existence of the African political organizations that began to emerge at the beginning of the $20^{\text {th }}$ century.

For example, in his journal Indian Opinion he wrote about Tengo Jabavu ${ }^{36}$ who worked towards establishing the first college for the Africans: ...it is not to be wondered at that an awakening people, like the great Native races of South Africa, are moved by something that has been described as being very much akin to religious fervour... British Indians in South Africa have much to learn from this example of self-sacrifice. ${ }^{37}$

34 Chapter 102: 'Heart Searchings' (p. 166) in M.K. Gandhi, An Autobiography..., p. 166.

35 Indian Opinion, 14 April 1906, in The Collected Works of Mahatma Gandhi, Vol. 5, p. 179.

36 John Tengo Jabavu (1859-1921), a Bantu activist, founder of the first independent newspaper in South Africa in the African language - IMVO Zabantsundu (launched in 1884); a member of the delegation protesting against the proposed Constitution of the South African Union in London (1909); in 1913 he backed the law on land, losing the support of his countrymen; in 1916 he was instrumental in the founding of the university in Fort Harare.

37 Indian Opinion, 17 March 1906, in The Collected Works of Mahatma Gandhi, Vol. 5, p. 125. 
And yet, even though Gandhi seemed to have realized that the discrimination of the "Coloured" (or any non-European) people in the long run affected all of the "non-Europeans," he still seems to have had some reservations in admitting the similarity of the position of Indians and the other "Coloured" fellow countrymen. Therefore, when he demanded the same rights in the Transvaal and the Orange State as in the Cape, he wrote: The petition is non-Indian in character, although British Indians, being Coloured people, are very largely affected by it [...]. Whilst, therefore, the Indian and non-Indian sections of the Coloured communities should, and do, remain apart, and have their separate organisations, there is no doubt that each can give strength to other in urging their common rights. Hence we have no hesitation in welcoming the document before us. ${ }^{38}$ Further on he explains his argument in the following way: [...] Association of Coloured People does not include Indians who have always kept aloof from that body. We believe that the Indian community has been wise in doing so. For, though the hardships suffered by those people and the Indians are almost of the same kind, the remedies are not identical. It is therefore proper that the two should fight out their causes, each in their own appropriate way. We can cite the Proclamation of 1858 (by Queen Victoria to India) in our favour, which the Coloured people cannot. ${ }^{39}$

For opposing a joint action with other oppressed people of South Africa, Gandhi has also been criticized among the South African Indians. However, he seems to have foreseen a possibility of applying his satyagraha to the struggle of the native population. Gandhi's biographer, rev. Joseph Doke, in an article published in the London Indian Chronicle in 1909, ascribes to him the following statements: When the moment of collision comes, if, instead of the old ways of massacre, assega $i^{40}$, and fire, the Natives adopt the policy of Passive Resistance, it will be a grand change for the Colony [...] If, then, the Natives accept the doctrines which are now so prevalent amongst the Indian community, South Africa need not fear the horrors of a racial uprising. It need not look forward to the necessity of maintaining an army to keep the Natives in awe. The future will be much brighter than its past has been. ${ }^{41}$

As much as Gandhi's attitude towards the liberation struggle of the Africans changed with the passage of time, his categorical view against taking any joint action did not. Even in the late 1920s, when he was ready to admit that: Indians have too much in common with the Africans to think of isolating themselves from them. They cannot exist in South Africa for any length of time without the active sympathy and friendship of the Africans. ${ }^{42}$ Though admitting the necessity of support, he obviously did not advocate for it on mutual terms.

Ten years later, in 1939, Gandhi gave a controversial interview to a Black Minister of the Dutch Reformed Mission and a member of the African National Congress, ${ }^{43}$

38 Indian Opinion, 24 March 1906, in The Collected Works of Mahatma Gandhi, Vol. 5, p. 133.

39 Indian Opinion, 24 March 1906, in The Collected Works of Mahatma Gandhi, vol. 5, p. 135.

40 Assegai or assagai (Arabic az-zagāyah, originally from Berber zajāya 'spear') - a weapon used for throwing or hurling (a light, wooden spear or javelin, pointed with iron).

41 J.J. Doke, M.K. Gandhi. An Indian Patriot in South Africa, London 1909, pp. 86-87.

42 Young India, 5 April 1928, in The Collected Works of Mahatma Gandhi, Vol. 41, p. 365.

43 R. Gandhi, The Good Boatman. A Portrait of Gandhi, New Delhi 1997, p. 218. More on S.S. Tema, 
Rev. S.S. Tema, who came from Johannesburg to the fourth meeting of the International Missionary Council, held in Tambaram (near Chennai) in December 1938. Tema interviewed Gandhi after the Conference, in January 1939. The text of the interview appeared in Harijan ${ }^{44}$ on February 18, 1939. When asked by Tema about his opinion regarding a possibility of forming an Indo-African united non-white front in South Africa, Gandhi answered categorically: It will be a mistake. You will be pooling together not strength but weakness. You will best help one another by each standing on his own legs. The two cases are different. The Indians are a microscopic minority. They can never be a menace to the white population. You, on the other hand, are the sons of the soil who are being robbed of your inheritance. You are bound to resist that. Yours is a far bigger issue. It ought not to be mixed up with that of the Indian. This does not preclude the establishment of the friendliest relations between the two races. The Indians can cooperate with you in a number of ways. They can help you by always acting on the square towards you. They may not put themselves in opposition to your legitimate aspirations, or run you down as "savages" while exalting themselves as cultured people in order to secure concessions for themselves at your expense. ${ }^{45}$

In the same interview he also advised the Africans of South Africa to "become African again" (like the Indians have become Indians after many decades of copying the British in their dress, behaviour etc.), and gracefully accepted when Tema proposed that the Africans would send to him for training one or two of our young men, who we are hoping will become leaders.

A few months later, answering some critical remarks made against his opinions voiced in this interview, he wrote: However much one may sympathize with the Bantus, Indians cannot make common cause with them. I doubt if the Bantus themselves will as a class countenance any such move. They can only damage and complicate their cause by mixing it up with the Indian, as Indians would damage theirs by such mixture. But neither the AICC resolution nor my advice need deter the Indians from forming a non-European front if they are sure thereby of winning their freedom. Indeed, had they thought it beneficial or possible, they would have formed it long ago. ${ }^{46}$

In June 1946 Gandhi stated in Harijan: It is time white men learnt to treat every buman being as their equal... ${ }^{47}$ These words could be read as an indication of a definite change in his views. A year later, in 1947, he sent a message to the Indian community in South Africa, saying that he believes in political cooperation among all the exploited races in South Africa [...] if it is wisely directed and based on truth and nonviolence. ${ }^{48}$

see: South African History Online, at <http://www.sahistory.org.za/people/s-s-tema-0>, 7 December 2014 .

44 Harijan (A Child of Hari, i.e. Vishnu) - the title of a weekly journal published by Mahatma Gandhi since 1932; also a term Gandhi coined to name the Dalits (traditionally known as the "Untouchables").

45 Harijan, 18 February 1939, in The Collected Works of Mahatma Gandhi, Vol. 74, p. 388.

46 The Hindu, 9 July 1939 (also Harijan, 15 July 1939), in The Collected Works of Mahatma Gandhi, Vol. 76, p. 98.

47 Harijan, 30 June 1946, in The Collected Works of Mahatma Gandhi, Vol. 91, p. 198.

48 Harijan, 25 May 1947, in The Collected Works of Mahatma Gandhi, Vol. 95, pp. 100-101. 


\section{CONCLUSION}

Gandhi's writings give a reasonably clear image of the actual relationship between the idea of satyagraha and South Africa, that is - the place where it originated. The two remain as parallel realities, yet to Gandhi "South Africa" hardly ever means anything more than the "Indian population in South Africa."

Therefore, the South African context seemed to have induced the advent of the idea of satyagraha only by affecting such levels of Gandhi's sensitivity which might have never been awakened had he not become a member of a minority deprived of its rights. ${ }^{49}$

He was, however, convinced that the two causes, the Indian and the native African, were of totally different nature, therefore he opposed taking joint actions against the European rule. And even though his attitude towards the native population gradually changed, he stood by this conviction almost till the end of his days.

Hence, it is possible to conclude that the "place" has certainly made Gandhi acutely aware of the position of an "oppressed people." And yet, he was not convinced whether his ideas could be referred to any other but the Indian population and, as it is widely known, these were the ideas that greatly influenced the course of the Indian struggle for independence.

However, the question of the degree to which the South African independence movement was influenced by Gandhi's ideas and how he is perceived in contemporary Africa, would need a separate discussion. The premonition that South Africa was most probably free from such influences finds proof in many of Nelson Mandela's speeches, including the one given on June 6, 1993 on the occasion of unveiling the Gandhi Memorial in Pietermaritzburg, where he said: This event is [...] very significant because we are unveiling here the very first statue of an anti colonial figure and a hero of millions of people world-wide. Gandhiji influenced the activities of liberation movements, civil rights movements and religious organisations in all five continents of the world. He impacted on men and women who have achieved significant historical changes in their countries [...]. Mahatma Gandhi came to this country 100 years ago, to assist Indians brought to this country as indentured labourers and those who came to set up trading posts. He came here to assist them to retain their right to be on a common voters roll. The Mahatma is an integral part of our history because it is here that he first experimented with truth; here that he demonstrated his characteristic firmness in pursuit of justice; here that he developed Satyagrah a as a philosophy and a method of struggle. [...]

Today as we strive to achieve a date for the first democratic elections in this country, the legacy of Gandhiji has an immediate relevance. [...] the [South African] Congress Movement was strongly influenced by this Gandhian philosophy, it was a philosophy that

49 As he admits in his Satyagraha in South-Africa, [...] the first batch of indentured labourers from India reached Natal on November 16, 1860, truly a fateful date for this history; had it not been for this, there would have been no Indians and therefore no Satyagraha in South Africa - p. 21. 
achieved the mobilisation of millions of South Africans during the 1952 defiance campaign, which established the ANC as a mass based organisation. [... $]^{50}$

These words of Nelson Mandela, as well as his other numerous statements of a similar nature, indicate that Gandhi's idea has certainly returned to the place of its origin and influenced the mentality of the South African native population. However, we intend to undertake this issue in the second part of the study, which will be based on the statements made by the main figures of the South African liberation movement.

\section{BIBLIOGRAPHY}

1911. Mines and Works Act no 12, Nelson Mandela Centre of Memory, at <https://www.nelsonmandela.org/omalley/index.php/site/q/03lv01538/04lv01646/05lv01736.htm>.

1913. Natives Land Act no 27, Nelson Mandela Centre of Memory, at <https://www.nelsonmandela.org/omalley/index.php/site/q/03lv01538/04lv01646/05lv01745.htm>.

1914. Indian Relief Act, Nelson Mandela Centre of Memory, at <https://www.nelsonmandela. org/omalley/index.php/site/q/03lv01538/04lv01646/05lv01746.htm>.

Balicki J., Historia Burów. Geneza państwa apartheidu, Wrocław 1980.

Bhana S., Indentured Indians in Natal 1860-1902. A Study Based on Ships' Lists, Durban 1987.

The Collected Works of Mahatma Gandhi Online, GhandiServe Foundation, at <http://www. gandhiserve.org/e/cwmg/cwmg.htm>.

Danver S.L., Native Peoples of the World. An Encyclopedia of Groups, Cultures, and Contemporary Issues, New York 2015.

Doke J.J., M.K. Gandhi. An Indian Patriot in South Africa, London 1909.

Du Bois D., 'Collusion and Conspiracy in Colonial Natal: A Case Study of Reynolds Bros and Indentured Abuses 1884,' Historia, Vol. 60, No. 1 (2015), at <http://dx.doi. org/10.17159/2309-8392/2015/v60n1a6>.

Du Bois D., 'The "Coolie Curse": The Evolution of White Colonial Attitudes towards the Indian Question, 1860-1900, Historia, Vol. 57, No. 2 (2012), at <http://www.scielo.org.za/ scielo.php?script=sci_arttext\&pid=S0018-229X2012000200002\&lng=en\&tlng=en $>$.

Du Bois D., The Evolution of the Indian Question in Natal - 1860-1897, at <http://www. kznhass-history.net/files/seminars/Dubois2011.pdf>.

Du Bois D., Labourer or Settler? Colonial Natal's Indian Dilemma 1860-1897, Durban 2011.

Feinstein Ch.H., An Economic History of South Africa. Conquest, Discrimination, and Development, New York 2005 (Ellen McArthur Lectures).

Gandhi M.K., An Autobiography or The Story of My Experiments with Truth, trans. by M. Desai, Ahmedabad (electronic document; no year of publication given).

Gandhi M.K., Satyagraha in South-Africa, trans. by V.G. Desai, Ahmedabad 2003 (electronic document published by Yann FORGET).

Gandhi R., The Good Boatman. A Portrait of Gandhi, New Delhi 1997.

50 Nelson Mandela's Speech at Unveilling of Gandhi Memorial, 6 June 1993, African National Congress, at <http://www.anc.org.za/show.php?id=4089>, 23 January 2015. 
A History of Indian Settlement in KwaZulu-Natal, at <http://www.zulu.org.za/archive/a-history-of-indian-settlement-in-kwazulu-natal-F58490>.

Huttenback R.A., 'Indians in South Africa, 1860-1914: The British Imperial Philosophy on Trial,' The English Historical Review, Vol. 81, No. 319 (1966), at <http://dx.doi.org/10.1093/ ehr/LXXXI.CCCXIX.273>.

Nelson Mandela's Speech at Unveilling of Gandhi Memorial, 6 June 1993, African National Congress, at <http://www.anc.org.za/show.php?id=4089>.

Padayachee V., 'Struggle, Collaboration and Democracy: The "Indian Community" in South Africa, 1860-1999,' Economic and Political Weekly, Vol. 34, No. 7 (1999).

Redding S., 'A Blood-Stained Tax: Poll Tax and the Bambatha Rebellion in South Africa', African Studies Review, Vol. 43, No. 2 (2000), at <http://dx.doi.org/10.2307/524983>.

Roberts P.E., History of British India under the Company and the Crown, London 1952.

S.S. Tema, South African History Online, at <http://www.sahistory.org.za/people/s-s-tema-0>.

Stuart J., A History of the Zulu Rebellion 1906 and of Dinuzulu's Arrest, Trial and Expatriation, London 1913.

Swan M., Gandhi. The South African Experience, Johannesburg 1985 (New History of Southern Africa Series).

Thompson L.M., Indian Immigration into Natal (1860-1872), Cape Town 1952.

Renata CZEKALSKA, Ph.D. - Associate Professor at the Institute of the Middle and Far East, Jagiellonian University, Krakow, Poland. She specializes in South Asian culture, the modern history of South Asia, and intercultural communication. Her recent publications include a hermeneutic analysis of the main thematic structures in the poetry of Ashok Vajpeyi, and a monograph dedicated to the enriching phenomenon of mutual transfer of intrinsic values in symbolic cultures.

Robert KŁOSOWICZ, Ph.D. - Professor at the Institute of Political Science and International Relations, Jagiellonian University, Krakow, Poland. He is a historian who specializes in history of international relations, interdependencies between diplomacy and the use of armed forces, international security issues, and military conflicts. The problems of the US foreign policy as well as the international relations in Sub-Saharan Africa also remain in the spectrum of his research interests. 